\title{
Erfaringer med e-læring i medicinsk engelsk. Udvikling af værktøjer til e-læring
}

\author{
Morten Pilegaard \\ Professor \\ Center for Medicinsk Fagsprog \\ Handelshøjskolen i Århus \\ mpi@asb.dk \\ http://www.asb.dk/staff/isek/mpi.aspx
}

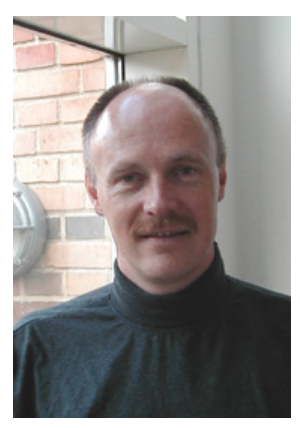

Morten Pilegaard er lektor i engelsk, professor i videndeling ved Danmarks Erhvervsforkningsakademi og leder af Center for Medicinsk Fagsprog på Handelshøjskolen i Århus. Morten Pilegaard arbejder aktuelt med udvikling af modeller for videnklynger inden for det sundhedsvidenskabelige og medicotekniske område samt udvikling af IKT-vœrktøjer, der understøtter videndeling og netvcrksbaseret laring. Centeret drives for eksterne forsknings- og udviklingsmidler og har et omfattende samarbejde med erhvervslivet og de lagevidenskabelige forskningsmiljøer.

\section{Introduktion}

Informations- og kommunikationsteknologien (IKT) og udviklingen af nye multimediesystemer skaber nye muligheder for integration af arbejds- og læringsprocesser - herunder for et mere intensivt og kvalitativt synergiskabende samarbejde mellem implicerede med forskellige baggrunde uafhængigt af tidsmæssige, geografiske og institutionelle afstande og erfaringsgrundlag. Teknologien understøtter tættere samarbejde i netværkslignende læringskonfigurationer. Denne artikel fokuserer på ideerne bag udviklingen af IKT-baserede værktøjer til understøttelse af netværksbaseret e-læring (NBL) (Goodyear 2001). En tidligere redegørelse for NBL-konceptet i forhold til medicinsk engelsk (ME) (Pilegaard 2003) har godtgjort, at online NBL indebærer et komplekst samspil mellem pædagogiske principper, teknologiske løsninger, og de uddannelsesmæssige og organisatoriske rammer.

ME er aktuelt i sin tredje udviklingsfase, hvor de IKT-relaterede udviklingsmæssige udfordringer fokuserer på at inddrage det kollaborative aspekt mere aktivt i både læringsprocesser i relation til selve kurset og i videnproduktionsprocesser, der omfatter postgraduate sprog- og kommunikationsmedarbejdere. Samtidig består udfordringen i at udvikle og implementere nye teknologier, der dels etablerer et tættere samspil mellem opgave, dialog og tekst, dels opsamler og systematiserer den fælles viden, der opbygges under lærings- og videnproduktionsprocesser, der foregår i tværorganisatoriske, tværinstitutionelle miljøer, her kaldet videnklynger.

Ved en videnklynge forstås en gruppe af virksomheder, organisationer og forsknings- og undervisningsinstitutioner, der via gensidig udveksling af viden og kompetencer er i stand til at produktudvikle og producere med et bedre resultat, end de ville have været i stand til enkeltvis. Dvs. at der gennem samarbejdet sker en konkret værdiforøgelse af den enkelte deltagers produkt. Tesen er, at en kobling af lærings- og videnklyngemiljøet vil skabe gensidig synergi og tilføre læringsdimensionen et nyt mere "virkelighedsnært" perspektiv af særlig betydning for efter- og videreuddannelse (EVU). 
De væsentlige styrende elementer i udarbejdelsen af IKT-redskaberne har i overensstemmelse hermed været 1) at de skulle facilitere online-NBL og dannelsen af virtuelle diskursfællesskaber (Kollock 1997; Smith \& Kollock 1999) på tværs af de traditionelle organisatoriske og institutionelle skillelinier; 2) at de i brugervenlighed og enkelhed skulle adressere behovet for praktiske, ressourceøkonomiske værktøjer til understøttelse af det sproglige arbejde i virksomheder, samtidig med at de i kompleksitet skulle honorere de akademiske krav til værktøjer anvendt i sprogundervisningsregi; 3) at de skulle understøtte kollaborativ læring og et erfaringsbaseret læringskoncept, der supporterer dialog i et socialkonstruktivistisk læringsperspektiv, hvor læring konciperes som et samarbejdsprojekt, der omfatter både daglige læringsprocesser i virksomheder og formaliserede læringsforløb.

\section{Materiale og metode}

Værktøjerne er udviklet med henblik på anvendelse i ME, som er et efter- og videreuddannelseskursus, der er tilrettelagt med maksimal teoretisk og praktisk relevans i forhold til de sproglige arbejdsopgaver i medikotekniske virksomheder, medicinalindustrien og i de sundheds- og lægevidenskabelige miljøer. ME har været afholdt i formelle uddannelsesforløb (ED og Cand.ling.merc.) som specialiserings- og tilvalgsfag og som målrettede efter- og videreuddannelseskurser i tæt samarbejde med virksomheder (fx Novo Nordisk) udbudt af Handelshøjskolen i Århus (ASB), samt som korte kompaktkurser udbudt af relevante brancheforeninger (Medicoindustrien, Lægemiddelindustriforeningen og Sprog \& Kommunikation).

Målgruppen er uddannelses- og erfaringsmæssigt samt geografisk heterogen: ansatte med en sproglig baggrund (bachelorer og translatører), der arbejder inden for medikosundhed eller i de sundhedsvidenskabelige miljøer og har brug for efter- og videreuddannelse i dansk og engelsk medicinsk fagsprog. Udviklingen af værktøjer til understøttelse af ME er derfor inspireret af et meget forskelligartet input.

Værktøjerne understøtter endvidere aktiviteterne i videnklyngen MEDVID, hvorved de studerende inddrages som en aktiv del af et mangefacetteret netværk, der aktivt eliminerer de traditionelle grænserne mellem uddannelsesmiljø, forskning og erhvervsliv.

\subsection{Videnklyngen MEDVID}

Aktørerne i videnklyngen MEDVID omfatter såvel kursister i ME-forløb, jfr. ovenfor, som alumner, der tidligere har deltaget i efter- og videreuddannelseskurser (EVU) og aktuelt arbejder i virksomheder inden for dels oversætterbranchen (blå) dels lægemiddelindustrien og virksomheder, der producerer medicinsk udstyr (gul) samt en række forsknings- og phd-miljøer (brun) særligt på DetSundhedsvidenskabelige Fakultet på Aarhus Universitet. 


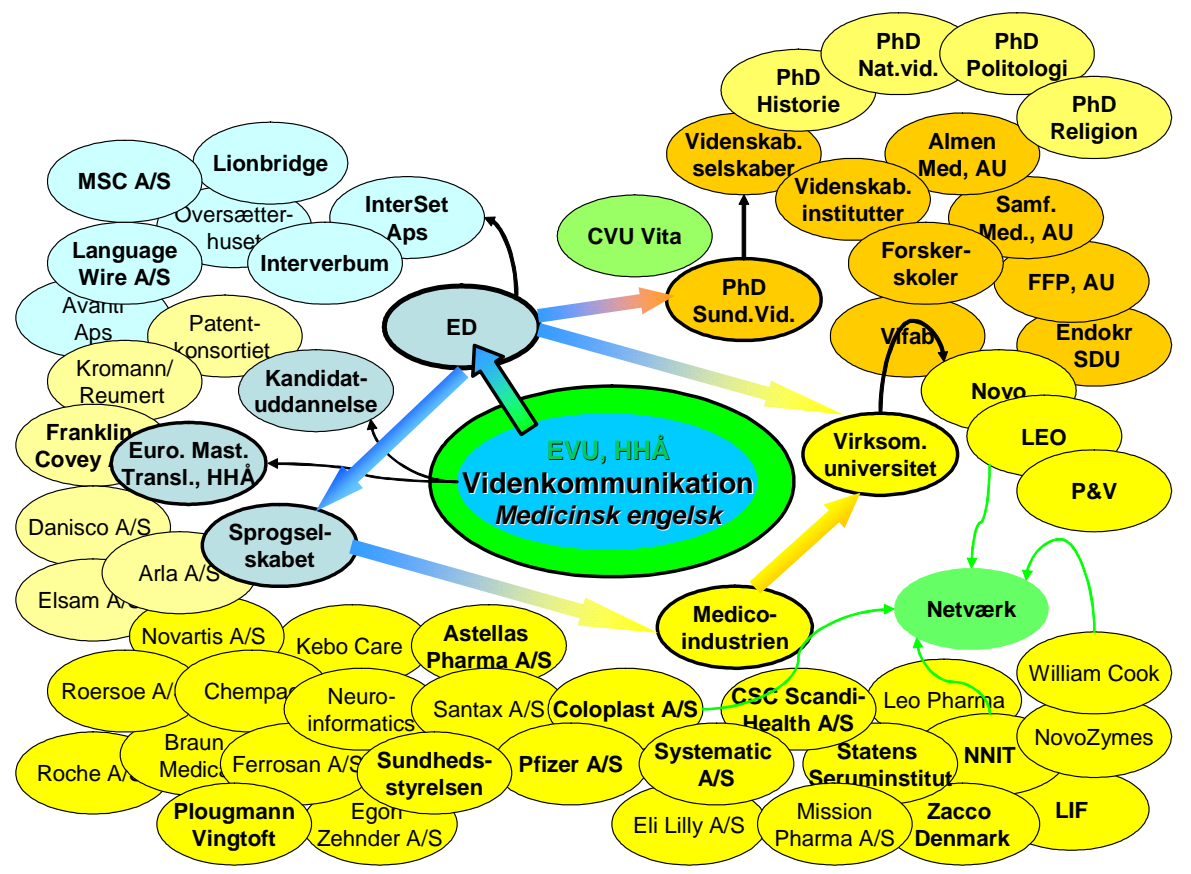

Figur 1. Videnklyngen MEDVID

Deltagernes brug af og daglige kontakt med de udviklede værktøjer varierer meget (jfr. nedenfor). I kraft af deltagernes forskellighed og fælles anvendelse af virtuelle værktøjer udviklet til at facilitere vidensmødet skabes et fælles virtuelt rum - et vidensfaciliterende rum ' $b a$ ' (Nonaka/Takeuchi 1995). Dette virtuelle rum fungerer som et mødested mellem teori og praksis, mellem viden og læring, mellem sprog og medicin/medicoteknik, samt mellem universitet og erhvervsliv og udgør således i et dynamisk videnfællesskab.

\subsection{Værktøjerne}

Værktøjerne er udviklet med forskellige primære formål for øje, men tjener overordnet samme formål: at facilitere vidensmødet mellem lærings- og arbejdsmiljøerne. For at understøtte ambitionen om at skabe et netværk af sammenhængende IKT-ressourcer integreres værktøjerne vha. en fælles applikation, SingleLogin, der gør det muligt at søge simultant i alle redskaber og administrere brugere på tværs af rettighedsniveauer og på tværs af applikationer og organisatorisk og/eller uddannelsesmæssig ramme afhængigt af de konkrete foreliggende opgaver. Sprogstuderende kan eksempelvis efter nærmere kriterier og godkendelse få privilegeret adgang til virksomhedsinterne distribuerede begrebs- og tekstdatabaser ifm. løsning af konkrete sprogopgaver.

Applikationerne kommer derved til at udgøre et sammenhængende net af ressourcer omkring en flerhed af aktører med forskellige baggrunde men et fælles behov for kobling af teoretisk og erfaringsbaseret viden om sprog og kommunikation. Der redegøres i det følgende for de centrale koncepter og deres udmøntning i udvalgte IKT-værktøjer anvendt i ME og videnklyngen MEDVID. 


\section{Et net af viden}

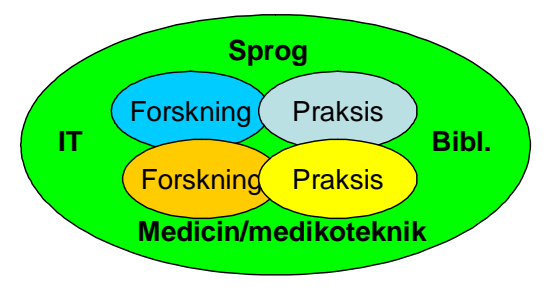

\section{Videnklyngen forbinder:}

$\checkmark$ Teori og praksis

$\checkmark$ Viden og læring

$\checkmark$ Sprog og medicin/mediko

$\checkmark$ Universitet og erhverv

\section{Et net af værktøjer}

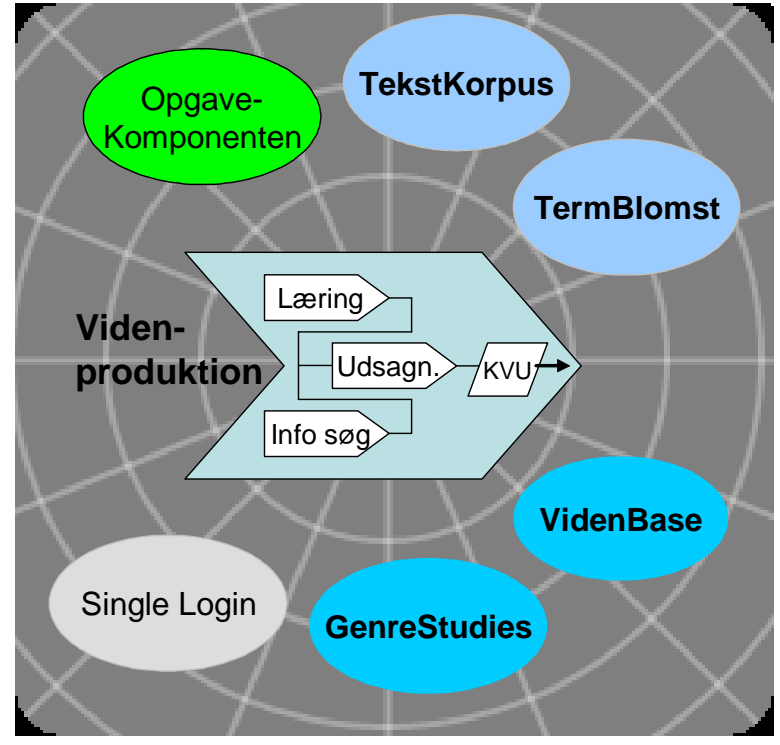

Figur 2. Viden-vœrktøjer

\subsubsection{TermBlomsten}

TermBlomsten er et koncept for netbaseret terminologistyring og videndelingsredskab, der imødekommer behovet for adgang til, styring af og organiseret deling af viden om begreber og fagterminologi inden for et bestemt område ved eksempelvis at give studerende adgang til viden om begreber, som de forstås og defineres i praksis- og forskningsmiljøerne, og adgang til validerede forslag til termers ækvivalenter på målsproget. Platformen er en netbaseret ordbog mellem to sprog, der tillader brugere dels at finde termer med tilhørende definitioner og oversættelse til engelsk, dels at tilføje nye opslag i egen termbank og redigere og kommentere eksisterende opslag og integrere disse i egen termbank. MedicinOrdbogen er et eksempel på TermBlomsten anvendt inden for fagområdet medicin og sundhedsvidenskab og sprogene dansk og engelsk.

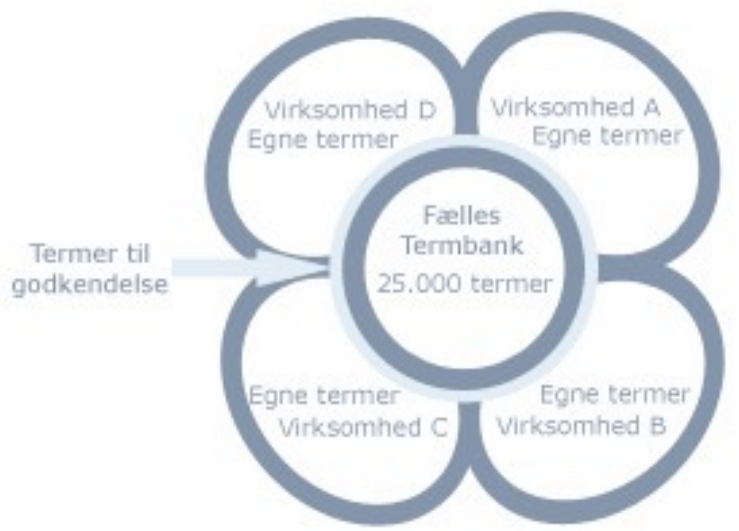

Figur 3. Termblomsten 
TermBlomsten er m.a.o. en dynamisk ressource, der understøtter den kollaborative intention i ME og i videnklyngen MEDVID - fordi den opfordrer til, at alle inden for videnfællesskabet kan deltage og præge redskabet med deres produktområde eller forskningskompetence. Hver deltagende virksomhed - i figuren symboliseret ved kronbladene - tildeles sin egen interne ordbog, hvorfra en administrator godkender sine brugeres forslag til den fælles kerne af opslag - for "studie-

virksomheden” den pågældende faglærer. Godkendes forslaget til virksomhedsekstern videndeling, skal det godkendes både sprogligt og fagligt af en valideringsenhed, før det bliver synligt for de andre virksomheder i TermBlomstens kerne.

De interne ordbøger er integrerede med TermBlomsten, men deres indhold er skjult for brugere fra andre organisationer. Man kan m.a.o. se fra bladet ind i kernen, men ikke vice versa. Studerende i "studie-virksomheden" indgår på linie med andre virksomheder - fra videnskabelige institutter på Aarhus Universitet, oversætterbureauer og internationale koncerner, fx Pfizer. MedicinOrdbogens kerne bestod oprindeligt af opslagene fra Gyldendals Medicinsk-Odontologisk Ordbog (danskengelsk-dansk), men kernen kan ikke længere umiddelbart identificerbar i MedicinOrdbogen, fordi en lang række brugere fra læringsmiljøer, it-virksomheder, medicinalindustrien, oversætterhuse og forskningscentre har tilføjet opslag i et betydeligt omfang.

MedicinOrdbogen fremstår i dag som et helt særegent resultat af mødet mellem brugere fra mange hjørner af medicinal- og sundhedsområdet med direkte adgang for studerende i ME læringsforløb. Fordelen er, at brugere får adgang til specialiseret og ny viden fra forskere, kolleger og ansatte fra andre brancher, der arbejder inden for samme felt - og for studerende at de får adgang til en viden, det normalt ville kræve mange ressourcer at indhente, og som læringsmiljøer kun sjældent har adgang til.

\section{Adgang til valideret viden og etablering af egen videnbase}

Gennem almindelige søgefunktionaliteter kan brugerne som udgangspunkt søge både i fælleskernen og i egen virksomheds interne ordbog, men det er muligt at begrænse sin søgning til kun at returnere opslag fra virksomhedsordbogen, og applikationen anvendes eksperimentelt af en række faggrupper på ASB.

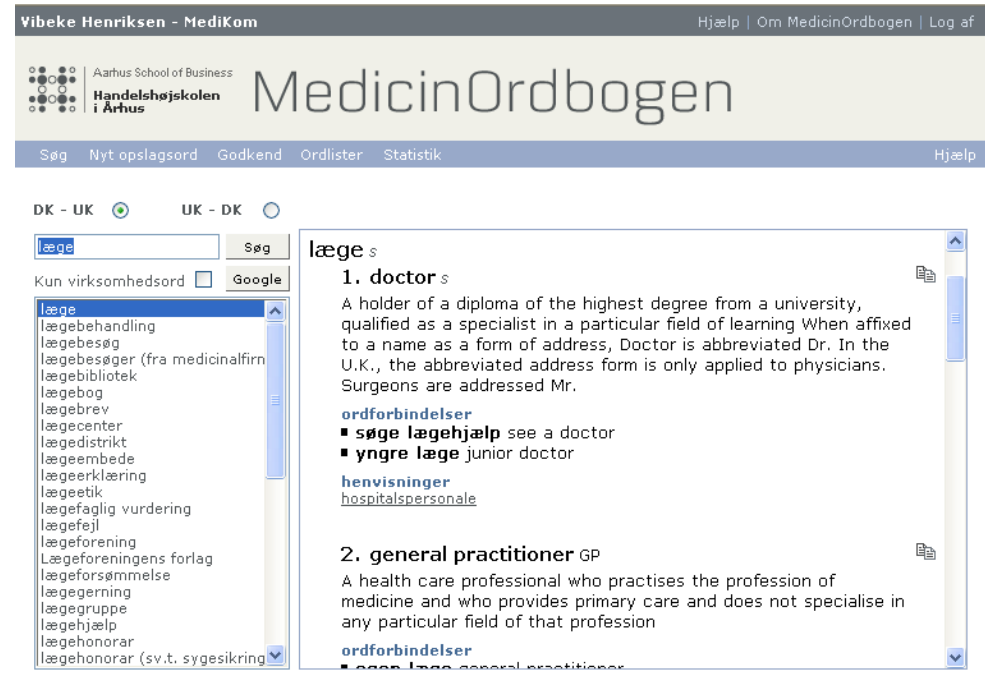

Figur 4. Eksempel på søgning i MedicinOrdbogen 
Alle brugere fra en virksomhed oprettes i samme gruppe, der automatisk tildeles egen ordbog, der kun er tilgængelig for gruppens brugere. Når der redigeres i et eksisterende opslagsord eller tilføjes et nyt opslagsord, bliver forslaget sendt til virksomhedens tekstadministrator, der kan vælge at afvise eller godkende forslaget til virksomhedens egen ordbog.

Når tekstadministratoren gemmer sine valg, bliver de godkendte forslag synlige i den interne ordbog. De afviste forslag slettes. Tilsvarende kan tekstadministratoren vælge at dele viden om begreber med de øvrige brugere gennem den ovenfor beskrevne valideringsproces. Der etableres dermed et dialektisk forhold mellem virksomhedsordbogen, der er udtryk for den sprogpolitik, virksomheden har valgt at implementere, og fælleskernen som et udtryk for branchens autoriserede oversættelser og etablerede begrebsdefinitioner. Dette giver de facto studerende stor frihed til at holde egen praksis op mod branchens normer og dermed træffe velkvalificerede valg i konkrete tekstproduktionsopgaver.

TermBlomsten er som koncept og i praksis en tosproglig applikation rettet mod et klart defineret segment med prædefinerede behov for sproglig viden. Værktøjets udvikling er bl.a. inspireret af brugere i såvel virksomheder som læringsmiljøer, og respons herfra har påvist et behov for et mere fleksibelt værktøj, der kan rumme en flerhed af fagområder, multiple sprog og tillade brugerne at oprette og vise informationskategorier tilpasset den enkelte virksomheds behov, uden at redskabets grundlæggende videndelingsstruktur og valideringsprocedure dermed berøres.

\section{TermShare}

Via EU-midler under progammet E-Contents er der i 2005 udviklet en applikation, TermShare, der bibeholder TermBlomstens grundlæggende koncept, men imødekommer ønsket om fleksibilitet. Sideløbende med it-udviklingen er der i tæt samarbejde mellem estiske, lettiske og danske epidemiologer og terminologer på eksperimentel basis udviklet indholdsdata i form af en engelsk-estisklettisk-dansk begrebsordbog inden for det epidemiologiske fagområde. Målgruppen herfor er primært sundhedsvidenskab og sundhedsøkonomer.

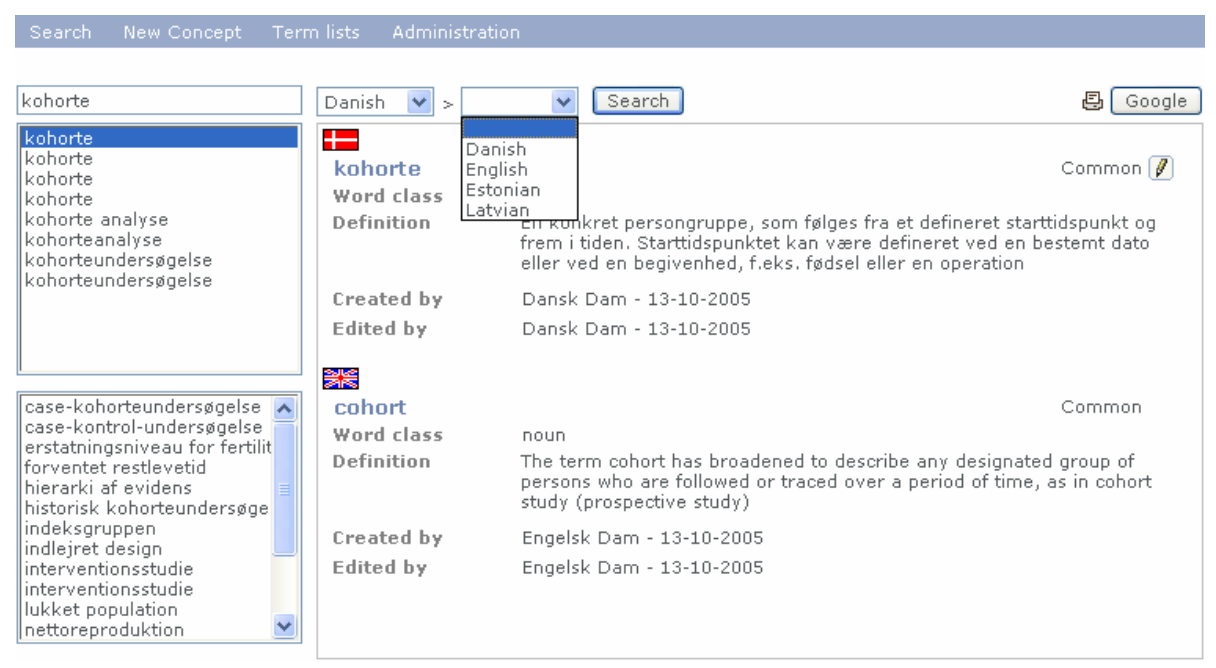

Figur 5: Eksempel på sprogvalg i Termshare

Til forskel fra TermBlomsten giver TermShare mulighed for at definere søgesiden og til kun at vise udvalgte, relevante informationskategorier og for at vælge mellem flere forskellige målsprog. Endvidere er der mulighed for at klikke sig ind på opslag, hvor søgeordet indgår i opslagets tekst. 


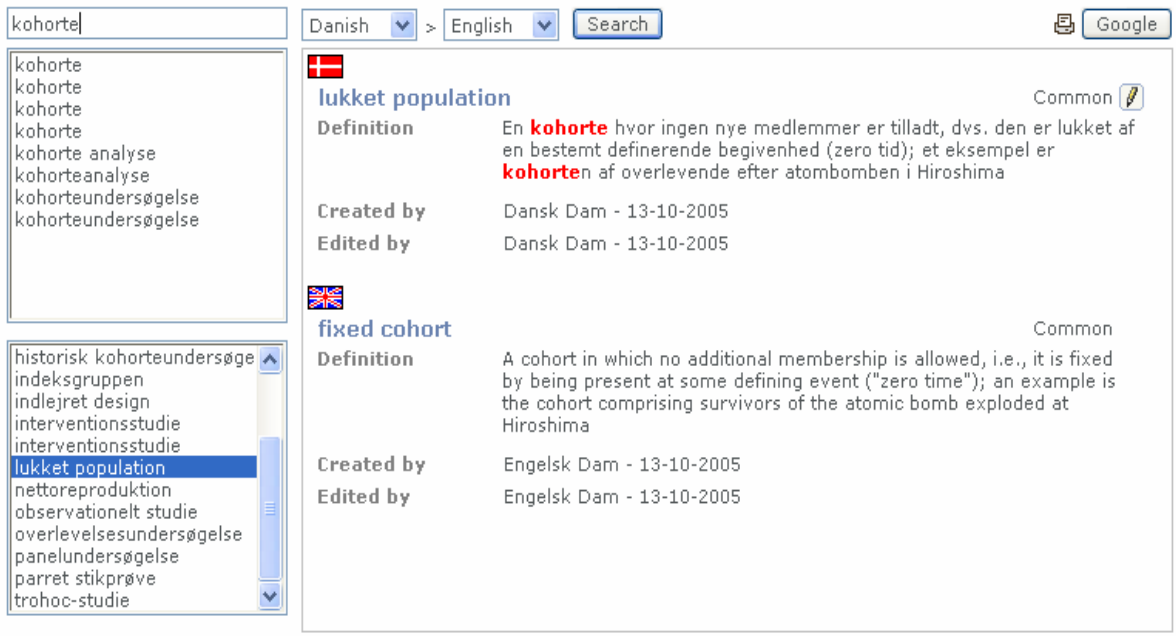

Figur 6:Eksempel på opslag i Termshare

De viste informationskategorier er afstemt efter fire forventede primære brugerprofiler, der afspejler den flerhed af brugere, hvis begrebsbaserede arbejde applikationen tænkes at understøtte, men applikationen tillader til enhver tid brugeren at definere og udvælge relevante informationskategorier som vist overfor.

Brugergrænsefladen er enkel nok til at tilskynde daglig brug og komplekst nok til at rumme en hel række relevante kategorier af information, hvoraf nogle er obligatoriske (ækvivalent på målsproget, ordklasse, uregelmæssig bøjning og forklarende definition), mens andre er valgfrie (kollokationer, eksempler, emneområde, amerikansk stavemåde, synonymer, krydsreferencer, eksterne links, forklaring til brug etc.).

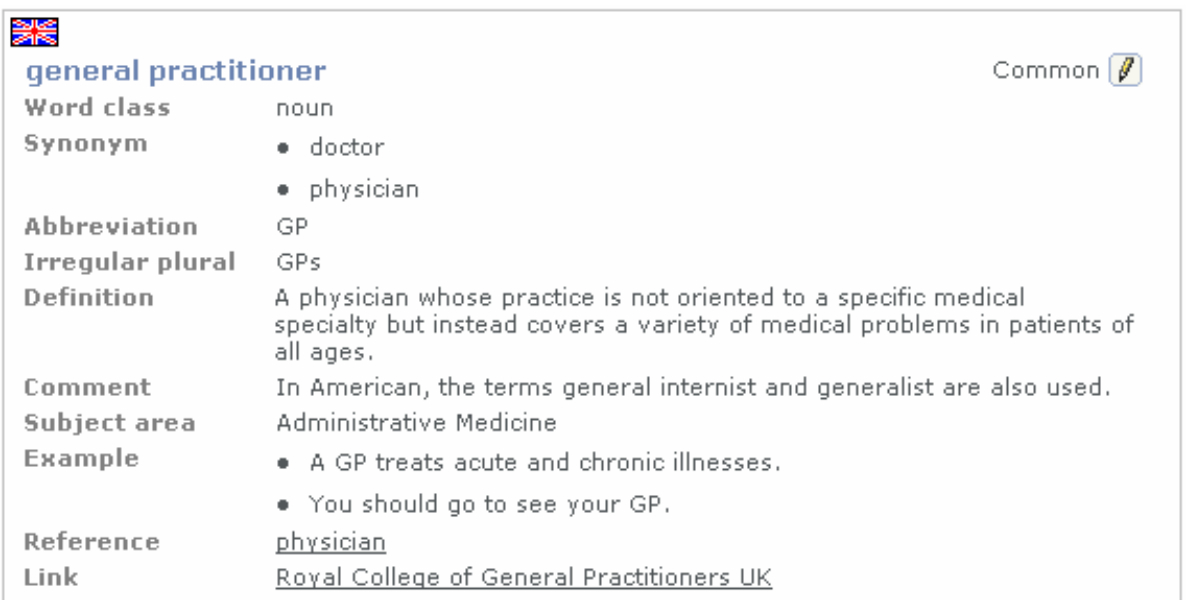

Figur 7: Eksempel på informationskategorierne i TermShare

\subsubsection{TekstKorpus}

Redskaberne til begrebs- og terminologibaseret videndeling suppleres af et tilsvarende redskab, TekstKorpus, til tekstbaseret videndeling med det primære formål at understøtte tekstproduktion, eksempelvis ifm. oversættelse, samt give en videnklynges deltagere adgang til hinandens tekstbaserede vidensamlinger. 
Medicinsk Korpus er et eksempel på TekstKorpus anvendt inden for fagområdet medicin og sundhedsvidenskab. Konceptet er det samme som bag TermBlomsten: En fælles mængde af delte tekster står i centrum for redskabet, og udenom har de deltagende organisationer etableret deres egne, interne tekstsamlinger, der kun kan tilgås af brugere i organisationen. Vælger man at dele sin tekst med de andre brugere, vil teksten efter godkendelse af virksomhedens superbruger blive synlig i fælleskernen, og alle brugere kan søge i den.

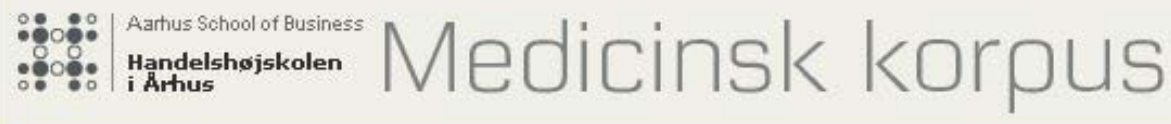

\begin{tabular}{|c|c|c|c|c|c|c|c|}
\hline virkning & Søg & Søg på & Dansk & $\checkmark$ & Oprindelse & Original & $v$ \\
\hline & øaning & Vis parallelle & Engelsk & $\checkmark$ & Teksttype(r) & Produktresumé & $\checkmark$ \\
\hline
\end{tabular}

Aldurazymes sikkerhed og virkning hos børn under 5 àr og hos patienter, der er mere end 65 ar, er ikke fastslàet, og ingen dosering kan anbefales til disse patienter.

Aldurazymes sikkerhed og virkning hos patienter med nyre- og leverinsufficiens er ikke vurderet, og ingen

dosering kan anbefales til disse patienter.

Før injektionen og i op til 24 timer efter hver injektion, anbefales det at tage et analgetikum med antipyretisk virkning for at begranse de influenza-lignende symptomer, der opstår i forbindelse med injektion af AUONEX.

Arava anbefales ikke til behandling af patienter under 18 ăr, da sikkerhed og virkning hos denne aldersgruppe ikke er blevet undersøgt.

Hos rhesusaber er der ved meget høje doser observeret abortfremkaldende virkning.

Søgningen gav 15 søgeresultater
The safety and efficacy of Aldurazyme in children below the age of 5 years and in patients older than 65 years have not been established and no dosage regimen can be recommended in these patients.

The safety and efficacy of Aldurazyme in patients with renal or hepatic insufficiency have not been evaluated and no dosage regimen can be recommended in these patients.

Prior to injection and for an additional 24 hours after each injection, an antipyretic analgesic is advised to decrease flu-like symptoms associated with AVONEX administration.

Arava is not recommended for use in patients under 18 years as its safety and efficacy have not been studied in this age group.

At high doses, in rhesus monkeys, abortifacient effects were observed.

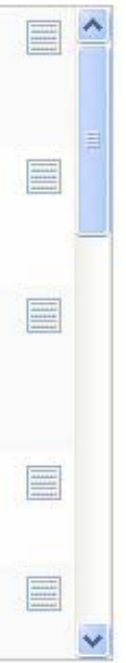

$$
\begin{array}{llll}
\text { Handelshøjskolen i Arhus } & \text { Fuglesangs, Allé } 4 & \text { Tlf. } & 89486580 \\
\text { Center for Medicinsk Fagsprog } & \text { DK - } 8210 \text { Arhus } & \text { E-mail } & \text { medicinordbogen(0)asb.dk }
\end{array}
$$

Figur 8: Eksempel fra TekstKorpus

Originale og oversatte tekster inden for genrer som videnskabelig artikel, indlægsseddel og produktresumé udgør fælleskernen. Teksterne i TekstKorpus er delt op i segmenter, der kan være enten syntaktisk eller semantisk motiverede, og organiseret efter tekstgenre. Brugere af Tekstkorpus, der søger på et ord eller en ordforbindelse, vil som resultat af søgningen få returneret de segmenter, der indeholder det søgte ord samt, hvis det er tilgængeligt og defineret i søgningen, det parallelle segment fra den oversatte version af kildeteksten. Herfra er der adgang til at se det valgte segments kildetekst i hel udgave og kildens bibliografiske data.

TekstKorpus fungerer således som bi- eller multilingvalt korpusredskab på linie med eksempelvis British National Corpus og WordNet. Rationalet bag applikationen er, adgang til et samlet materiale af tekster fra et bestemt fagområde understøtter dokumentations- og teksproduktionsprocesser, in casu produktion af korrekte og konsistente tekster inden for det medicinske og sundhedsfaglige om- 
råde. Den sætningsbaserede søgning i en given dokumentsamling sikrer ideelt oversætteren en ensartet terminologi uanset branche og giver virksomheden et redskab til effektivisering af dens tekstproduktion og dokumenthåndtering.

Aktuelt håndterer Medicinsk Korpus en lang række validerede tekster, eksempelvis de sidste fem årgange af nyhedsbreve på engelsk og dansk fra Statens Serum Institut. Tekster oplægges enten manuelt ved simpel copy-paste, som kommasepareret fil eller via en Trados WinAlign-fil.

\subsubsection{OpgaveKomponenten}

OpgaveKomponenten er et netbaseret undervisningsredskab under udvikling, der primært faciliterer kommunikationen mellem underviser og studerende i forbindelse med besvarelse, kommentering og returnering af tekstproduktionsopgaver. Konceptet er udviklet i samarbejde med Hypergenic A/S og har i tidligere versioner været pilottestet i ME (Pilegaard \& Harbo, 2002).

Rationalet bag applikationen er at integrere visning af opgave, besvarelse og vejledende løsning i samme vindue for derved at etablere et samlet overblik over den aktuelle opgave, samt at etablere mulighed for at opbygge, distribuere og dele opgavekommentarer på tværs af læringsmoduler og på tværs af traditionelle skel mellem undervisere og studerende. Applikationen understøtter dermed dels det kollaborative element, dels etableres en effekt- og forløbsbevidsthed, der ikke er til stede i en normal modulorienteret undervisning. Gennem muligheden for åbent, netbaseret samarbejde på tværs af studerende og undervisere understøtter applikationen endvidere erfaringsbaseret læring og team-teaching.

Underviseren kan med OpgaveKomponenten stille en opgave, hvortil der knyttes udførlige vejledende kommentarer, og den studerende kan herefter løse opgaven individuelt og dermed få adgang til en vejledende besvarelse. Underviseren retter den studerendes opgave via redskabets kommenteringsværktøj og returnerer den til den studerende, der kan sammenligne sin besvarelse med andre studerendes besvarelser samt egne tidligere besvarelser og derved monitorere egen læringsudvikling. Herved muliggøres individuelle læringsforløb, hvor studerende kan trække på tidligere, akkumuleret viden, idet kommenteringer af vejledende opgavebesvarelse fastholdes og kontinuerligt suppleres af såvel faglærer som tidligere studerende.

Underviseren har adgang til samme sammenligningsmuligheder og kan fx sammenligne hyppigheden af en bestemt type fejl og dermed justere sin undervisning løbende, så den tager højde for de aktuelle studerende og deres behov. Endvidere kan underviseren fastholde, supplere og udbygge egne kommentarsamlinger samt give andre faglærere adgang til at kommentere specifikke kommentarer. Opgaver og kommentarer kan m.a.o. genbruges fra studerende til studerende, fra hold til hold, og fra faglærer til faglærer, hvilket øger mulighederne for omfattende og individualiseret kommentering og effektiv ressourceallokering.

\section{Oprettelse, redigering og kommentering af opgave}

Underviseren kan enten vælge at stille en ny opgave eller genbruge en tidligere stillet opgave. I menuen gives mulighed for at udfærdige en udførlig opgaveinstruks og -beskrivelse, hvorefter opgaveteksten kopieres ind segment for segment. Ønsker opgavestiller at tilføje en vejledende besvarelse, gøres der plads til to parallelle kolonner. Opgavestiller kan også hente en opgave, der tidligere er blevet oprettet og delt af undervisere på andre OpgaveKomponenter. 


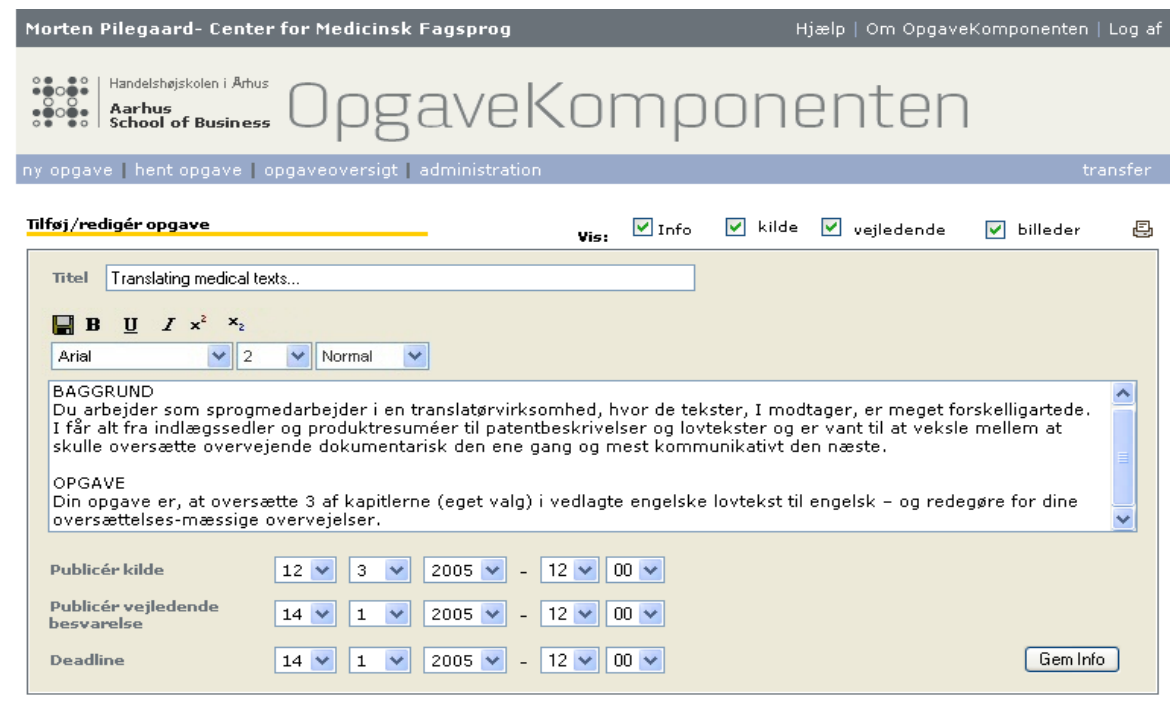

Figur 9: Eksempel på oprettelse af en opgave i OpgaveKomponenten

Underviseren kan redigere i opgaveteksterne og de studerendes besvarelser ved at klikke på et af opgavens segmenter, der herefter omdannes til en editor, der tillader underviseren at redigere segmentets tekst. Hvis underviseren ønsker at knytte en kommentar til det givne tekstsegment i opgavetekst, opgavebesvarelse eller eget modelforslag, klikker vedkommende på kommentarikonet og tilføjer sin kommentar i et nyt vindue. Underviseren kan søge i tidligere oprettede kommentarer, sammenligne kommentarer og genbruge materiale og formuleringer fra tidligere.

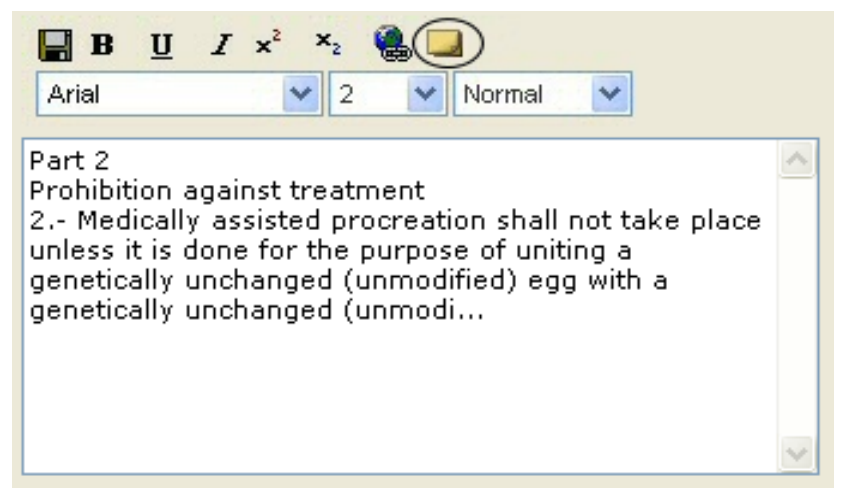

Figur 10: OpgaveKomponentens editor, der tillader underviseren at redigere segmentets tekst.

\section{Opgavebesvarelse}

Studerende, der logger på OpgaveKomponenten, præsenteres for egen Opgaveoversigt, der rummer alle returnerede, afleverede og ikke-besvarede opgaver fra kurset, og hvorfra der er adgang til at se underviserens informationer om opgaven og indtaste eller indkopiere besvarelsen. Efter aflevering har den studerende ikke længere adgang til at redigere i opgaven. Efter besvarelse og aflevering vil den studerende med det samme få vist opgaveteksten, egen besvarelse og underviserens vejledende besvarelse i samme vindue som parallelle segmenter for at gøre sammenligning enklere. Via opgaveoversigten har den studerende også adgang til at sammenligne egen besvarelse med andre studerendes besvarelser. 


\section{Integreret layout}

Efter underviserens kommentering af besvarelsen får den studerende adgang til den kommenterede opgave via opgaveoversigten. Kommentarer vises som tekst fremhævet med gul og ses ved mouse over. Generelle kommentarer til kildetekst og vejledende oversættelse kan ses af alle, medens kommentarer til en specifik studerendes besvarelse alene kan ses af underviseren og den pågældende studerende.

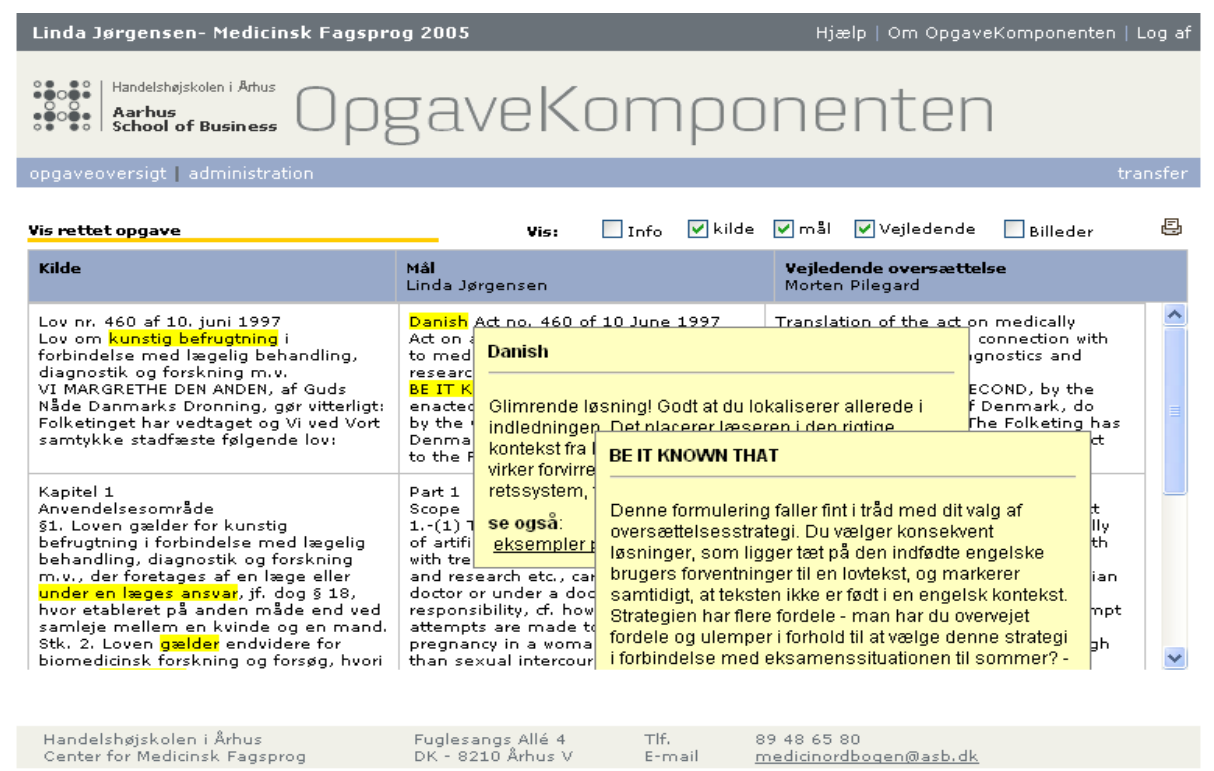

Figur 11: Eksempel på fremhæevede kommentarer i OpgaveKomponenten

Opgaversamlinger indgår som integrerede vidensamlinger tilknyttet specifikke e-læringsbaserede moduler. I ovenstående eksempel på oversættelse af en lovtekster vil der typisk være flere undervisere, der arbejder med samme emne, som vil trække på samme tekst- og notesamling og opnå såvel faglige som læringsmæssige synergieffekter.

\section{Videndeling og læring}

Den løbende udvikling af ME er foregået i faser, som på skift har sat fokus på de tekniske og pædagogiske aspekter. Hver udviklingsfase er blevet efterfulgt af en evaluering foretaget dels for at inspirere planlægningen og udviklingen af nye NBL kurser udbudt af CMS, dels som led i den løbende kvalitetsudvikling af det aktuelle kursus.

Den nuværende udviklingsfases har sat fokus på teknologisk udvikling af værktøjer, der adresserer videndeling og kobler de miljøer, hvori ME foregår, med de videns- og arbejdsmiljøer, hvor arbejdet med de sproglige genstandsfelter i ME traditionelt foregår, dvs. oversættervirksomheder, sundhedsvidenskab og virksomheder, der producerer farmaceutiske præparater og medicinsk udstyr. 


\section{Viden - en dynamisk proces}

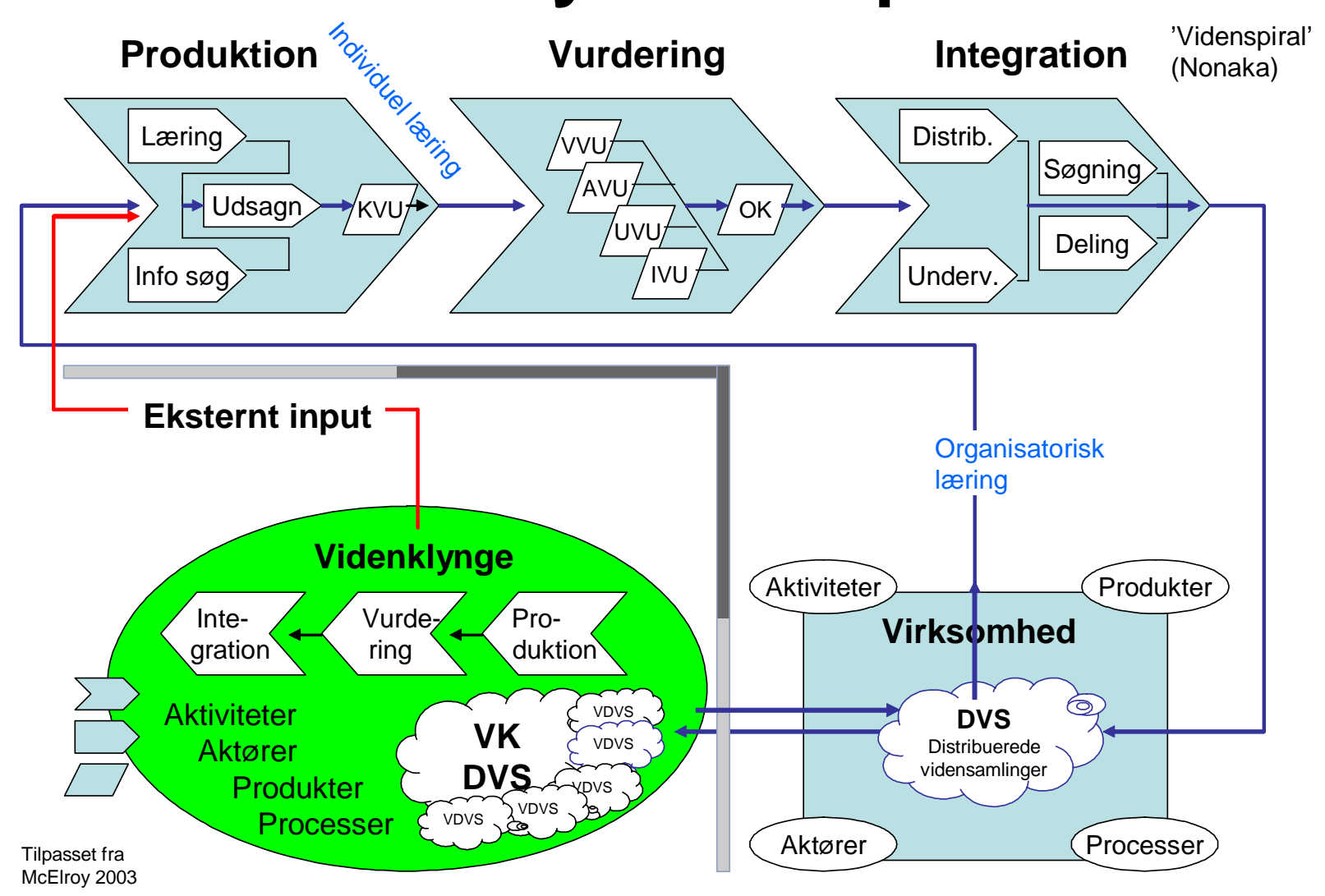

Figur 12: Viden - en dynamisk proces

TermBlomsten og TekstKorpus understøtter dynamiske vidensproduktions-, vurderings- og integrationsprocesser inden for og mellem videnklyngens deltagende virksomheder - herunder også "studentervirksomheden". Videnklyngen er dermed med til at åbne nye perspektiver og muligheder for netværksbaseret læring.

\subsection{Den nødvendige videndeling}

Der er i disse år særlig opmærksomhed på samarbejdet mellem forskning og erhvervsliv, hvor skodderne mellem de respektive videns- og praksismiljøer fortsat ofte er næsten vandtætte. Det manglende samarbejde betragtes som en af de væsentligste hindringer for udfoldelsen af såvel videns- som produktionspotentialer.

Gennem etablering af videnklyngen og anvendelse af videnklyngens redskaber i læringsmiljøet skabes en samarbejdsmodel, der gør det muligt for private virksomheder og offentlige forskningsog uddannelsesinstitutioner at udveksle viden og for 'communities of practice' at eksplicitere og distribuere fællesskabernes tavse viden.

Modellen er med til at skabe betingelser for en eksplicitering af den viden, der til enhver tid er i en virksomhed og i 'communities of practice', og skabe grobund for den potentielle synergieffekt, der 
ligger i mødet mellem det anvendelsesorienterede virksomhedsperspektiv og det teoretiske universitetsperspektiv.

Videnklyngen kan betragtes som værende opbygget af en flerhed af overlappende, komplementære videns- og praksisfællesskaber, og den udgør en dynamisk eller "levende" videnbase, der modsat databaser muliggør eksplicitering, håndtering og deling af viden. Hvor videndeling traditionelt foregår virksomheds- eller koncerninternt, og hvor 'communities of practice' normalt et lokale svar på lokale problemer, er videnklyngen en model, der understøtter effektiv videndeling på tværs af organisatoriske, faglige og andre skel og ekspliciterer organisationens erfaringsbaserede eller 'tavse' viden.

Frem for alene at være et spørgsmål om organisationens interne ressourcefordeling placeres den praktiske viden centralt og på linje med universiteternes teoretiske viden, og der skabes således et potentielt frugtbart møde mellem teori og praksis: de private virksomheder får adgang til ny viden fra forskningen, og de offentlige forsknings- og uddannelsesinstitutioner får adgang til viden, som den opfører sig i kontekst, og som den bruges i praksis.

\section{Konklusion}

I udviklingen og implementeringen af nye værktøjer, der understøtter lærings- og videnproduktionsprocesser inden for virtuel EVU, er kollaborativ læring eller læring gennem "communities of practice” (Wenger 1998) af afgørende betydning - ikke kun for produktet, men også for processen.

Det er væsentligt, at de udviklede værktøjer etablerer et tæt samspil mellem distribuerede videnbaser samt opsamler, systematiserer, validerer og distribuerer den fælles viden, der opbygges under lærings- og videnproduktionsprocesser. Læring bør ideelt foregå i tværorganisatoriske, tværinstitutionelle miljøer, såkaldte videnklynger, som kan være med til at åbne nye perspektiver og muligheder for netværksbaseret læring.

\section{Litteratur}

Goodyear, P. (ed.) (2001): Effective networked learning in higher education: notes and guidelines. Centre for Studies in Advanced Learning Technology, University of Lancaster, UK. Networked Learning in Higher Education Project (JCALT). Vol. 3.

Kollock, P. (1997): Design principles for online communities. The Internet and Society: Harward Conference Proceedings. Cambridge Mass: O’Reilly \& Associates“

Nonaka og Takeuchi (1995). The Knowledge-Creating Company. Oxford University Press

Pilegaard, Morten: “Netværksbaseret læring” (Networked learning), Hermes 2003

Pilegaard, Morten; Harbo, Karen: "Medicinsk engelsk som fjernundervisningskoncept” (Medical

English as concept in distance teaching). Bibliotekets Nyhedsbrev no. 4, ASB, 2002.

Smith, M./Kollock, P. (eds) (1999): Communities in cyberspace. London: Routledge.

Wenger, E. (ed.) (1998): Communities of practice.

Cambridge: Cambridge University Press. 